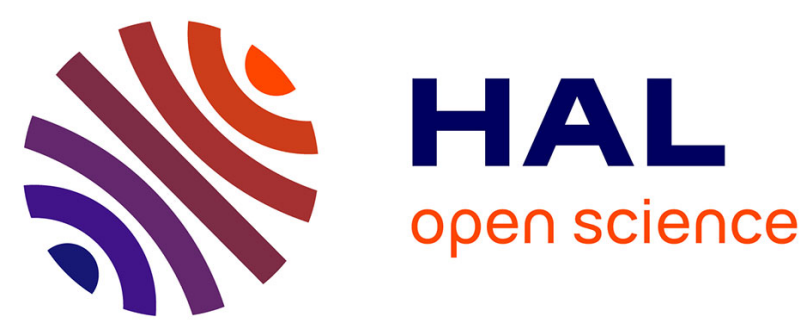

\title{
Competing Visions: Domestic Forests, Politics and Forest Policy in the Central Western Ghats of South India
}

Ajit Menon, Christelle Hinnewinkel, Claude Garcia, Sylvie Guillerme, Siddhartha Krishnan, Nitin Rai

\section{To cite this version:}

Ajit Menon, Christelle Hinnewinkel, Claude Garcia, Sylvie Guillerme, Siddhartha Krishnan, et al.. Competing Visions: Domestic Forests, Politics and Forest Policy in the Central Western Ghats of South India. Small-Scale Forestry, 2009, 8, pp.515-527. 10.1007/s11842-009-9096-0 . hal-01174860

\author{
HAL Id: hal-01174860 \\ https://hal.science/hal-01174860
}

Submitted on 10 Jul 2015

HAL is a multi-disciplinary open access archive for the deposit and dissemination of scientific research documents, whether they are published or not. The documents may come from teaching and research institutions in France or abroad, or from public or private research centers.
L'archive ouverte pluridisciplinaire HAL, est destinée au dépôt et à la diffusion de documents scientifiques de niveau recherche, publiés ou non, émanant des établissements d'enseignement et de recherche français ou étrangers, des laboratoires publics ou privés. 


\title{
Competing Visions: Domestic Forests, Politics and Forest Policy in the Central Western Ghats of South India
}

\author{
Ajit Menon · Christelle Hinnewinkel · \\ Claude Garcia $\cdot$ Sylvie Guillerme $\cdot$ Nitin Rai • \\ Siddhartha Krishnan
}

Accepted: 26 July 2009

(c) Steve Harrison, John Herbohn 2009

\begin{abstract}
Rural people in developing countries including India continue to access a number of types of 'forests' to meet specific needs such as fuelwood, fodder, food, non-timber forest produce and timber for both subsistence and income generation. While a plethora of terms exist to describe the types of forests that rural people use - such as farm forests, social forests, community forests and small-scale forests - the expression domestic forest has recently been proposed. Domestic forest is a term aimed at capturing the diversity of forests transformed and managed by rural communities and a way to introduce a new scientific domain that recognises that production and conservation can be reconciled and that local communities can be effective managers. This paper argues in the context of the central Western Ghats of south India that while the domestic forest concept is a useful umbrella term to capture the diversity of forests used by rural people, these domestic forests are often not autonomous local forests but sites of contestation between local actors and the state forest bureaucracy. Hence, a paradigm shift within the forest bureaucracy will only occur if the scientific forestry community questions its own normative views
\end{abstract}

\author{
A. Menon $(\bowtie)$ \\ Madras Institute of Development Studies, 79, 2nd Main Road, Gandhinagar, Adyar, Chennai \\ 600020, India \\ e-mail: ajit@mids.ac.in \\ C. Hinnewinkel \\ Laboratoire ADES-CNRS, Universite des Sciences et Technologies de Lille 1, Lille, France \\ C. Garcia \\ CIRAD and French Institute of Pondicherry, 11 St. Louis Street, PB 33, Pondicherry 605001, India \\ S. Guillerme \\ Laboratoire GEODE, CNRS, UMR 5602, Toulouse, France \\ N. Rai · S. Krishnan \\ Ashoka Trust for Research in Ecology and the Environment, 659 5th A Main Road, Hebbal, \\ Bangalore 560024, India
}


on forest management and sees forest policy as a means to recognise local claims and support existing practices of forest dependent communities.

Keywords Rural forestry · Community-based forest management · Decentralisation · Forest claims

\section{Introduction}

Michon et al. (2007) proposed the concept of domestic forest as an overarching term to capture the diversity of forests local people use and the specificities of forest management by local users in the context of tropical forestry. While most definitions of forests have been technical in nature, stipulating extent and density of tree cover, domestic forests is a social term. Domestic forest highlights the breadth of forests transformed by rural people for meeting their needs including minimalistic activities such as selective clearings and more intensive activities including silviculture and agriculture in forests. The opening up of forest canopy to promote some utilizable forest species and the replacement of undergrowth by crops such as coffee are examples of practices that transform and domesticate forests (Michon and de Foresta 1997). Moreover, Michon et al. (2007) argued that these domestic forests are not only ecologically transformed by people using them but also managed by local communities. The resultant socio-ecosystem differs from the one shaped by professional production-oriented forestry and even from multipurpose forestry. "It is "a forest for living", a forest that integrates production and conservation with social, political, and spiritual dimensions' (Michon et al. 2007, p. 17). As the authors argued, the domestic forest concept is also meant to encourage a movement away from professional 'scientific' forestry towards a more peoplecentred forestry through highlighting an alternative epistemology of forest management.

At one level, the stage seems set for such an epistemological shift given the apparent acceptance of the discourse of decentralised forest management both internationally and within nation-states (Kennedy et al. 2001; Millenium Ecosystem Assessment 2005). However, as Michon et al. (2007, p. 17) also argued, for such a shift to take place it 'not only calls for a revision of the normative, conceptual, and technical frameworks of forestry but also for deep changes in political, legal and regulatory frameworks'.

This paper focuses specifically on the political and legal obstacles of moving to a new paradigm of decentralised forest management. It is argued, in the context of the central Western Ghats of south India, that while the domestic forest concept is useful to identify the diversity of forests that people use (and hence claim) to meet forest produce needs regardless of legal rights or restrictions, equally important is to explore the manner in which state policies constrain the autonomy of local actors to manage these forests. Forests and forest policy are inherently political and hence there are competing visions as to by whom and how domestic forests should be managed. The gap in perceptions and use of forests by local, state and global actors results in disputes over desirable forest management strategies, with powerful 
non-local actors including state and scientific entities determining policy on forest use and management. For a paradigm shift to happen in practice requires that 'old school' forestry professionals see forest policy as a way to recognise local claims and not as a way to define what forests local people can use and manage as currently policy continues to do.

\section{Usefulness of the Domestic Forest Concept}

Rural communities, especially in developing countries, continue to depend on forest resources to meet a number of needs, including material for house construction, fuelwood, fodder for livestock, and food and other non-timber forest products (NTFP) for consumption and income generation. A host of terms exist to depict these forests and the variety of ecological and social dimensions to them, including local forests, community forests, traditional forests, sacred forests, peasant forests, forest gardens and agroforests (Gadgil and Vartak 1975; Balent 1996; Long and Nair 1999; Kusel and Adler 2003; Wiersum 2004; Garcia and Pascal 2006; Michon et al. 2007). Broadly speaking, an ecological continuum exists between farm forestry initiatives that are entirely man-made plantations of trees, through agroforestry systems that are often a mix of trees and agricultural crops, to intermediate forests that are 'natural forests' worked by communities (Belcher et al. 2000). In terms of social characteristics, forests encompass private forests, social forests and community forests, with a variety of tenurial and ownership characteristics possible. Hence, forests could range from complex multistoried agroforestry systems managed by a community such as the damar forests of Indonesia (described by Michon 2005 and Michon et al. 2007) to temperate private forests of farmers of south-western France (discussed by Balent 1996 and Sourdril et al. 2006).

Given the variety of terms currently used to describe and analyse forests which are used for people-oriented and community-based sustainable development, how does the term domestic forest add value in India? First, this term serves as an umbrella expression to highlight the mix of forests that rural communities access to meet particular livelihood needs. ${ }^{1}$ It is difficult to understand people-forest dynamics by isolating a type of forest used by people from other forest types because, as Bruce (1989) argued, rural households utilize tree products regardless of the type of land on which they are found. Second, the term domestic forest highlights the claims that rural communities place on particular forests including perhaps state-controlled forests. This is important in the Indian context where there is some fear that recent efforts by the Ministry of Environment and Forests to define what a forest is continue to be a way for the state to claim control over more forest land. Third, the term domestic forest, unlike small-scale forestry, allows for the recognition that even forests used primarily for industrial use might be used for

\footnotetext{
1 These needs are both economic and cultural. It is not surprising, therefore, that a vast literature exists focusing on sources from which rural communities meet these 'forest produce needs', the manner in which various forests are utilized by communities, the benefits they derive from them, and the systems through which they are managed (Jeffery 1999; Sundar et al. 2001; Lele 2007; Sarin et al. 2003).
} 
domestic purposes as well. Hence, the term 'small-scale forest' might not be inclusive enough when delineating the forests that rural communities utilize.

While the reasons given above highlight the conceptual value of the term domestic forest, its applicability might well vary widely from region to region. For example, domestic forests in much of the developed world might include mostly private forest areas. However, in a developing country context-including in India where the state claims direct ownership over approximately $70 \%$ of the forested land and where people have used this forest land historically to meet their forest produce needs - such a limited purview would appear short-sighted. In other words, domestic forests need to be defined differently in particular spatial domains.

\section{Domestic Forests in the Central Western Ghats}

The districts of the Nilgiris, Wayanad and Kodagu in the southern states of Tamil $\mathrm{Nadu}$, Kerala and Karnataka are heavily forested areas in the central Western Ghats (Fig. 1). Forests vary from patches of evergreen forest ${ }^{2}$ exposed to the monsoon, to moist deciduous forest ${ }^{3}$ and dry deciduous forest ${ }^{4}$ in the rain shadow of the region. These forests belong to a biodiversity hotspot hosting 4,000 species of flowering plants of which nearly 38\% are endemic (Ranjit Daniels 2001). In addition to officially classified forests, the physical landscape has a high density of trees outside forests in tea and coffee plantations predominantly where trees act as shade cover. Also, many small farmers, especially in Kerala and the Karnataka Western Ghats, have home gardens with trees such as arecanut tree (Areca catechu), coconut tree (Cocos nucifera), mango tree (Mangifera indica) and jack fruit tree (Artocarpus integrifolia). In other words, the landscape of the region is a mosaic of trees inside and outside officially defined forests.

All of these wooded spaces, be it forest as defined by the Forest Department or agricultural land, are domestic forests. They have been transformed by local people ${ }^{5}$

\footnotetext{
${ }^{2}$ Major plant species of evergreen forest include Palaquium ellipticum, Artocarpus hirsuta, Cullenia excelsa, Elaeocarpus tuberculatus, Vateria indica, Calophyllum elatum, Mesua ferrea, Bombax ceiba, Garcinia Morella, Schleichera oleosa, Cullenia excelsa, Mangifera indica, Mallotus philippinensis, Olea dioica.

3 Major plant species of moist deciduous forest include Bambusa bamboos, Dalgerbia latifolia, Terminalia paniculata, Terminalia tomentosa, Tectona grandis, Lagerstroemia lanceolata, Adina cordifolia, Grewia tilaefolia, Bombax ceiba, Anogeissus latifolia, Xylia xylocarpa.

${ }^{4}$ Major plant species of dry deciduous forest include Anogeissus latifolia, Terminalia chebula, Terminalia tomentosa, Terminalia paniculata, Grewia tilaefolia, Albizia odoratissima, Pterocarpus marsupium, Lagerstroemia parviflora, Dalgerbia paniculata, Zizyphus xylopyrous, Randia dumatorum, Bauhinia racemosa, Diospyrous melanoxylon.

5 Present day Nilgiris, Wayanad and Kodagu comprise a wide diversity of communities both adivasi (tribal) and non-adivasi, agricultural and non-agricultural, and some who have been there for many hundreds of years and other more recent arrivals. In the Nilgiris, the main adivasi communities are the Todas and Kotas in the plateau areas, Irulas and Kurumbas on the outer slopes and the Paniyans, Kurumbas and Kattunayakans in the lower western parts of the district. In Wayanad, the main adivasi groups are the Paniyans, Adiyans, Jen Kurubas and Kattunayakans whereas in Kodagu the main adivasi groups are the Jen Kurubas, Betta Kurubas and the Yeravas. Today most of these communities, aside from the Todas, cultivate land or work as agricultural labourers, some of them because their 'traditional'
} 

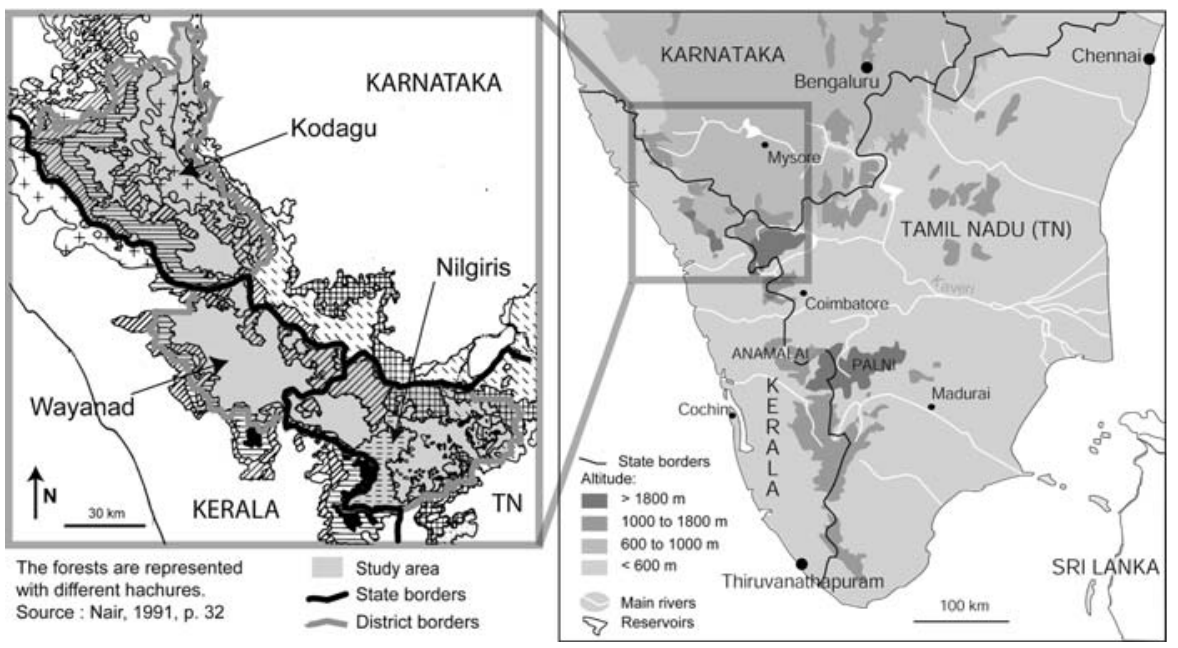

Fig. 1 Kodagu, Wayanad, Nilgiris forested districts of the central Western Ghats

in order to meet their forest produce requirements. Table 1 offers a simplified categorization of which forest produce needs are obtained ${ }^{6}$ from which land types and ownership categories. As the table illustrates, communities depend to a great extent on state-owned reserved forest (including protected areas) which comprise on average $45 \%$ of the total area of the region (Forest Survey of India 2003) for meeting their basic need of fuelwood as well as other needs including collecting NTFP. Historically, the distinction between forest and agricultural land was not clear because agriculture was also practiced in what later became state forests. Fuelwood is also collected from private land, especially estate land, primarily by those who work on the estates. Revenue land, under the control of the Revenue Department, is less prominent in the region but some burial grounds, which are also sites of fuelwood collection, are located on this land. In the Western Ghats, domestic forests include plantations on private land, multicrop smallholder land, community land belonging to the Revenue Department or panchayats ${ }^{7}$ used for collection of forest-based products, afforested land (social forestry), community forest land including burial areas and co-managed forest-including traditional community forest management, joint forest management (JFM) and ecodevelopment sites and even reserved forests.

Many of these domestic forests provide supra-local goods including timber for industry as well as supra-local services including biodiversity conservation and

\section{Footnote 5 continued}

rights to forests have been curtailed. Amongst the non-adivasi communities, there are communities including the Badagas in the Nilgiris, the Chettis in Gudalur of the Nilgiris and in Wayanad and the Kodavas and Gowdas in Kodagu who have been there for many centuries, as well as more recent immigrants including a number of landed communities from the plains as well as Sri Lankan repatriates.

${ }^{6}$ Some forest uses, such as those in protected areas, are de facto not de jure. For instance, as per the Wildlife (Protection) Act, hunting is prohibited everywhere but yet it occurs in some forests.

\footnotetext{
7 A panchayat is an elected village council.
} 


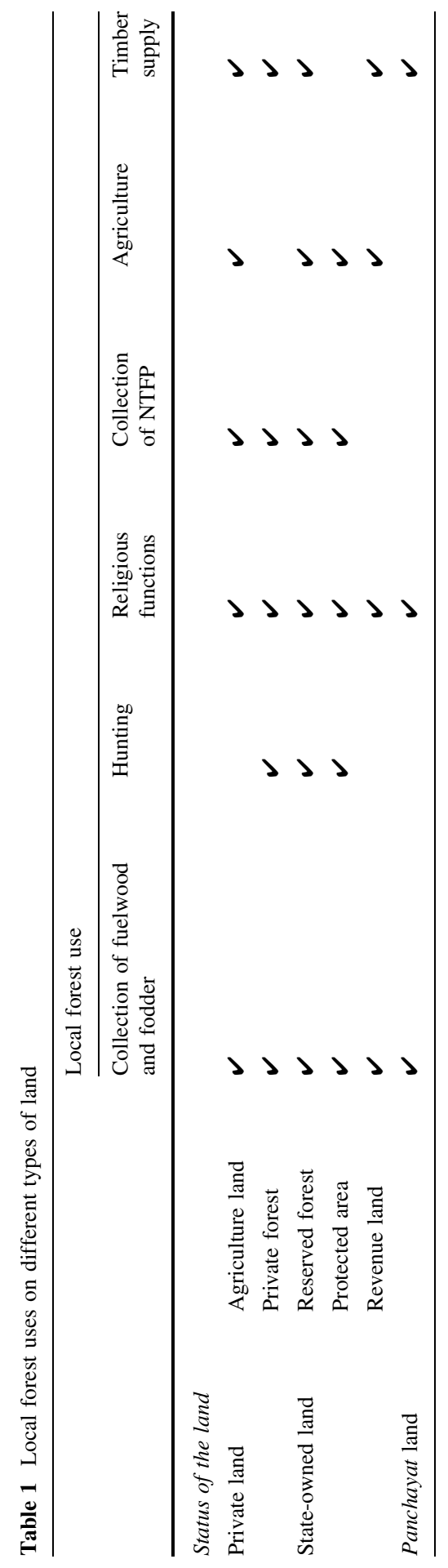


watershed protection. As a result, in the central Western Ghats, more so than in nonhill areas, forest legislation and policy impose tight restrictions on local felling and use of tree species. Table 2 provides details of laws in Tamil Nadu, though Karnataka and Kerala have broadly similar laws. While forest legislation in the form of national and state-level forest acts historically aimed at the appropriation by the state of forest resources for timber production, nowadays the restrictions on local forest use are imposed in the name of ecological services, including soil preservation, biodiversity conservation (vegetation cover, wildlife, heritage), climate regulation or in general 'ecological and environmental security'. ${ }^{8}$

The state-level forest acts ${ }^{9}$ admit few local rights to usufruct in state-owned forests. Separate acts exist to regulate the felling of trees in private forests and even on private agricultural land. For example, in Tamil Nadu, change of land use of a private forest is prohibited by Section 1 of the Tamil Nadu Preservation of Private Forest Act. ${ }^{10}$ The cutting of trees is prohibited by Section 3 of the Tamil Nadu Hill Areas (Tree Preservation) Act. This Act also defines rules pertaining to permission to cut trees under specific conditions. ${ }^{11}$ However, while permits are allowed for cutting trees, further cumbersome and administratively lengthy restrictions exist for transporting timber. ${ }^{12}$

The forests of the Western Ghats therefore, while domesticated, are not necessarily examples of autonomous decentralised local management, but rather the product of a complex relationship between the state and local actors mediated by forest policy. Farmers grow trees on their land but the selection of trees is shaped by policies that make it easier to grow particular species. Moreover, as people cannot obtain permits to transport trees, they plant trees mostly for fuelwood, fruit, green manure and shade for their crops. For many small farmers the permit system for cutting and transport of timber acts as an obstacle to tree cultivation on private land because they are unable to invest time into obtaining the required clearances and even if they do the financial returns are minimal. Hence, the extent to which domestic forests in the Western Ghats can provide examples of decentralised forest management is debatable. Rather, it might be more useful to use the domestic forest

\footnotetext{
${ }^{8}$ In other states, laws exist that regulate the use of forest produce in the name of supra-local functions. For example, the Karnataka Preservation of Tree Act of 1976 was passed to regulate tree feeling on private land in order to 'restore ecological balance'.

9 Forest Acts define the process to notify declare an area as a reserved forest under the control of the state. In reserved forests, access to forest resources is limited; felling timber and hunting are totally prohibited and other practices are controlled.

${ }^{10}$ This Act also requires a committee to be set up to regulate sale, mortgage and leasing of private forest land exceeding 2 ha as well as to regulate the cutting of trees grown on private land.

11 The Hill Area Committee can allow permission to cut trees if regeneration of trees 'of an equal number of the same or other suitable species' (Section 3 of the Tamil Nadu Hill Areas (Tree Preservation) Act) takes place and the person to whom the permission is granted deposits a sum as security (Section 9-2 of the Tamil Nadu Hill Areas (Tree Preservation) Rules).

12 In exercise of the powers conferred by Sections 35 and 36 of the Tamil Nadu Forest Act, 1882, the Tamil Nadu Timber Transit Rules of 1968 regulate timber transit from both state forests and private land. Some trees are exempted from the purview of these rules. Similar rules exist in other states but the list of tree species varies: 61 species are exempted in Kerala, 36 in Tamil Nadu and 14 in Karnataka. Two species belong to the three lists, namely Erythrina indica and Hevea brazilensis.
} 


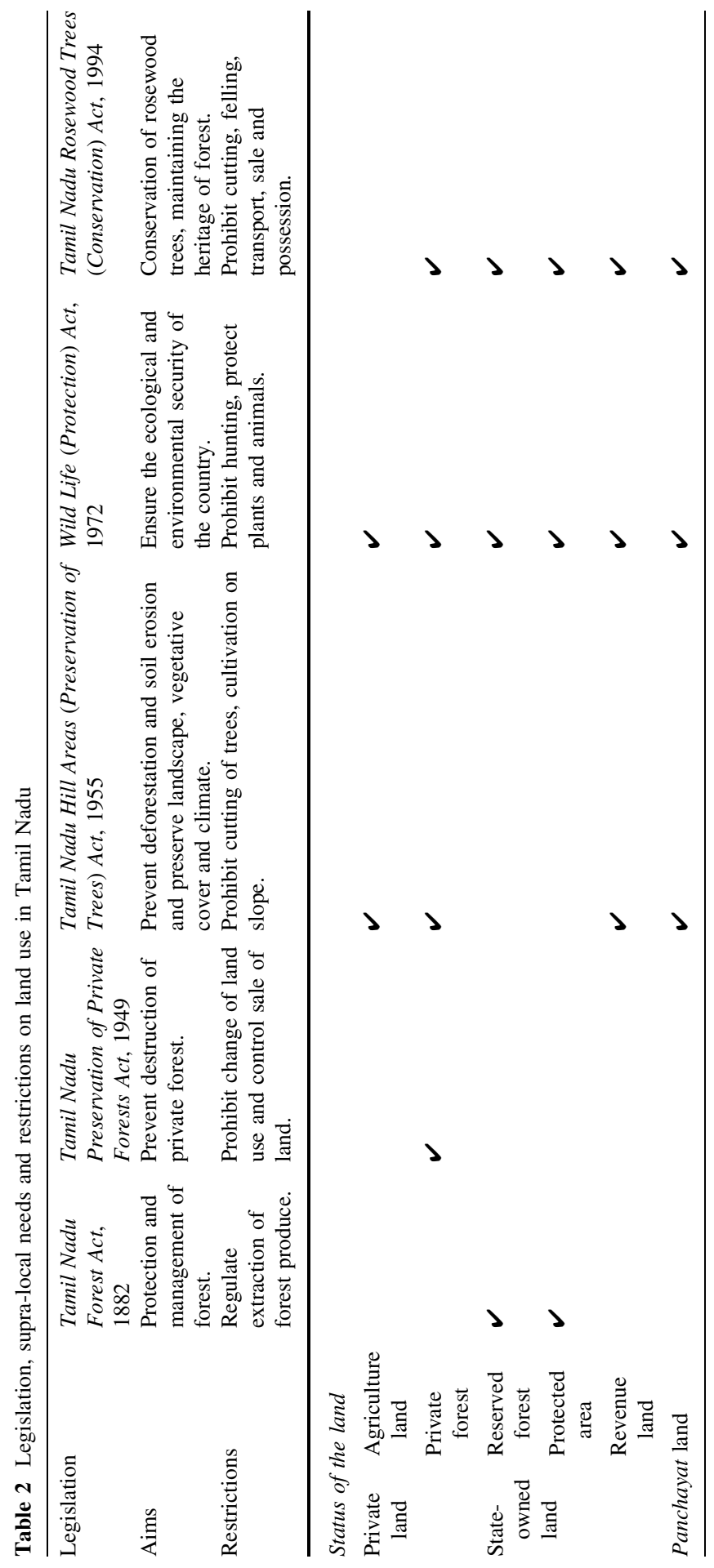


concept as a way to identify forests that local people use to meet their forest produce needs and then examine how forest policy enables or obstructs effective local management of these forests. To see domestic forests today as cultural insignia of the community misses the fact that they are also essentially political constructs shaped by state policy.

\section{Domestic Forests: Towards a New Paradigm}

Michon et al. (2007) suggested that the concept of domestic forest is a means of introducing a new paradigm for the 'combined benefit of forest science and forest people'. As argued above, domestic forests of Western Ghats are rarely autonomous forests that could provide the basis for such a paradigm shift. However, equally important is to see whether forest policy has room for recognising the legitimacy of the plethora of forest landscapes transformed by people. On paper, the 1988 National Forest Policy specifically prioritises the socio-economic needs of forest dependent communities alongside that of environmental conservation (Government of India 2006). Unlike in the past when local demands on forests were seen to be inimical to supra-local priorities of timber production, forest policy at the central level today recognises that local communities can help promote environmental conservation. Despite this, in the central Western Ghats, people continue to be excluded from the vast majority of reserved forests. Although communities continue to use these forests either by paying fees to the Forest Department for example for grazing or simply 'encroaching' forest land, access is either at the discretion of Forest Department personnel or potentially costly if laws are violated.

Over the last two decades, the state has involved communities in co-management strategies (in India, notably joint forest management (JFM)), which explicitly expands the range of domestic forests ostensibly recognised by the state. However, in the central Western Ghats, JFM confers few powers to the established forest protection committees. While on paper the Forest Department is supposed to comanage these forests with the Village Forest Committee (VFC) and prepare a microplan and in return give communities access to fuelwood and NTFP, villagers have derived few benefits. Moreover, local people say they were not even consulted about the choice of species that were planted as part of this co-management and that they have no rights to planted trees. Rather, in many parts of the region, co-management is a means by which the Forest Department promotes its tree planting agenda. In some areas of Wayanad, people have been provided with income generating activities in exchange for reducing their use of the forest but the benefits seem minimal and no substitute for access to domestic forests.

Policies of decentralisation also appear to be challenged by the Forest Department's attempts to expand its own jurisdiction. For instance, devarakadus (sacred groves in Kodagu) which were managed by local communities for many years are now under the jurisdiction of the Forest Department. In the Gudalur region of the Nilgiris, decentralisation is yet to be implemented as the state attempts to bring more land under its control that historically was leased out to janmis (lessees). While local communities argue that many of these areas are cultivated land, the 
Forest Department says they were forests and hence should be theirs. ${ }^{13}$ In other words, the thrust continues to be very much to put more forests under the control of the Forest Department.

The Forest Department also continues to promote a policy of 'trees on private land' which is aimed at reducing dependence on forests and delegitimising claims on these forests, However, this is an old paradigm. Social forestry in the 1970s and 1980s focused on planting trees on common and private land. It was largely unsuccessful because where people did grow trees (mostly farm forestry on private land), they did so for commercial purposes and continued to use reserved forests for fuelwood and fodder needs. This further confirms the fact that forests have plural uses and preventing use by either criminalizing use or diverting dependence is unjust.

There are a number of reasons for the state's reluctance to accept a paradigm shift, all of which are political in nature. First, the state continues to see forests as state property. It believes that the Forest Department must be the overseer of forests and those priorities including socio-economic ones need to be managed by the forest bureaucracy. Second, the state continues to believe in 'scientific' forest management. It believes that local communities are unable to manage forest resources in a sustainable way given their increasing demands on forest resources, a concern aggravated by the fact that people persist within poverty realms and hence their needs are fueled by external demands and market forces. The Forest Department must, therefore, introduce principles of scientific forestry in terms of species choice, felling strategies and even new inputs such as clonal seeds. Local ecological knowledge, however defined, is marginalised in such a discourse and so too is recognition of the social dimensions of forests (Temperton 2007). This is aggravated by a professional culture within the forest bureaucracy that continues to see forestry as science and hence efforts at collaborating with local communities potentially unscientific and of secondary importance. Third, the Forest Department is highly suspicious of claims of local communities to forest land. The recent passing of the Scheduled Tribes and Other Forest Dwellers Act 2006, which implicitly recognises that tribal (and other forest-dwelling) communities have domesticated reserved (or state-owned) forests has resulted in considerable fear within the forestry establishment. This fear has resulted at times in unwillingness to recognise historical claims. In Gudalur region of the Nilgiris, the Forest Department in fact is claiming a large area claimed by farmers as well.

While the rhetoric of decentralisation might be pervasive, in practice it is yet to set in the central Western Ghats. Domestic forests are hence very different from the transformed and managed landscapes referred to by Michon et al. (2007). If domestic forests are to be forests where local communities have rights of use and management responsibilities, then the central focus of debate around decentralised

\footnotetext{
${ }^{13}$ Land in Gudalur historically belonged to the Nilambur of Kovilagam and was leased out initially to estates and subsequently to small-scale farmers as well. Much of this land was forest, some of which is now cultivated. The conflict is therefore both about who this land belongs to and what land use should be applied. The Janman Estate (Abolition and Conversion into Ryotwari) Act, 1969, resulted in the Forest Department and other state agencies claiming much of this land. Currently a number of court cases are pending with regard to the status of large areas of both forest and cultivated land.
} 
forest management should pertain to what these forests should be. Clearly these perceptions vary with the stakeholder. From the perspective of the forest bureaucracy, forest policy should provide viable alternative forest sites away from state-owned forests from which farmers can meet their forest produce needs. From the perspective of the 'community', their historical rights to forest land should be recognised. However, given the highly political character of forest management in the central Western Ghats, the fear of farmers is that any land deemed to be forest will lead to more state control. Similarly, the identification of forests as domestic will make the state and scientific fraternity wary of the loss of state control to regulate access and ensure management. Nonetheless, as the term domestic forest was coined to identify forest transformed by people, it is useful for at least that purpose. Perhaps, one can go further by saying that forests are inherently domestic and that state policies should be aware of this as opposed to attempting to lable particular forests domestic and others non-domestic, again creating a potentially artificial distinction that strengthens the state's claims over land deemed to be 'nondomestic'. In other words, a new epistemology of forest management will require the state to engage much more actively with the political process in which forest priorities are defined and then provide the necessary institutional conditions that allow for effective decentralised management. This will not exclude a role for state agencies nor will it imply that all forms of local management are sustainable given the fact that the open access nature of many forests can lead to free-riding.

\section{Conclusion}

Domestic forest is a useful concept to highlight the range of forests that rural communities depend upon but a number of obstacles remain in translating this into a new paradigm of forest management, at least in the Indian context. The 'should be' of domestic forests as viewed primarily by the forestry establishment continues to drive forest policy and hence does not recognise the range of domestic forests that people use. More participatory co-management policies are either limited in scope-i.e. constrained to areas where forests are degraded —or limited in the extent of devolution to local communities. In the context of the central Western Ghats, the new focus of forest policy appears to be the promotion of tree growing on private land with the aim to delegitimise claims to forest.

Clearly, there are differing epistemological and ontological foundations to perceptions about domestic forests. These are shaped by different political priorities. While the concept as used by Michon et al. (2007) was introduced to capture the diversity of forests transformed by rural people to meet their needs, under the prevailing policy regime, it may be used to prescribe particular forests for local use, while keeping other forests under strict state control for conservation or production. If that indeed happens, then the introduction of the domestic forest concept would not have served its main purpose. What remains to be seen, therefore, is whether the scientific forestry community is willing to engage increasingly with local communities in a search for sustainable forest management solutions that recognise local needs in forests. 
Acknowledgements This paper was prepared after a workshop on 'Rural Forests in India' held in Coimbatore in October 2007 under the aegis of the 'Public Policies and Traditional Management of Trees and Forests (POPULAR)'-ADD project funded by the Agence Nationale de la Recherche (France). The authors wish to thank all the participants of this workshop for their inputs.

\section{References}

Balent G (ed) (1996) La Forêt paysanne dans l'espace rural: biodiversité, paysages, produits. Etude Recherche No. 29, INRA, Toulouse (France). Available via INRA. http://www.inra.fr/internet/ Departements/SAD/rub3resu/EtudEtRech/etudrech29.htm. Accessed 17 Jan 2008

Belcher B, Michon G, Angelsen A, Ruiz-Perez M, Asbjørnsen H (2000) Workshop keynotes. In: Asbjørnsen H, Angelsen A, Belcher B, Michon G, Ruiz-Peres M, Wijesekara VPR (eds) Proceedings of the workshop: Cultivating (in) tropical forests? The evolution and sustainability of systems of management between extractivism and plantations, Kraemmervika, Lofoten, Norway, 28 June-1 July 2000, pp 9-40. Available via European Tropical Forest Research Network. http://www.etfrn.org/ETFRN/workshop/lofoten/etfrn_series_3.pdf. Accessed 10 Feb 2008

Bruce JW (1989) Community forestry-rapid appraisal of tree and land tenure. Community forestry note 5. FAO, Rome

Forest Survey of India (2003) State of forest report-2003. Forest Survey of India, Dehradun

Gadgil M, Vartak VD (1975) Sacred groves of India-a plea for continued conservation. Bombay Nat Hist Soc J 72(2):312-320

Garcia C, Pascal JP (2006) Sacred forests of Kodagu: ecological value and social role. In: Cederlöf G, Sivaramakrishnan K (eds) Ecological nationalisms: nature, livelihoods and identities in south Asia. University of Washington Press, London, pp 199-229

Government of India (GoI) (2006) Report of the National Forest Commission. Ministry of Environment and Forests, New Delhi. Available via Ministry of Environment and Forests. http://www.envfor. nic.in/divisions/nfr.html. Accessed 25 Jan 2008

Jeffery R (ed) (1999) The social construction of Indian forests. Manohar, New Delhi

Kennedy JJ, Thomas JW, Gluek P (2001) Evolving forestry and rural development beliefs at midpoint and close of the 20th century. For Policy Econ 3(1-2):81-95

Kusel J, Adler E (eds) (2003) Forest communities, community forests: struggles and successes in rebuilding communities and forests. Rowman and Littlefield, Lanham, MD

Lele S (2007) A 'defining' moment for forests? Econ Political Wkly 42(25):2379-2383

Long AJ, Nair PK (1999) Trees outside forests: agro-, community and urban forestry. N For 17:145-174

Michon G (ed) (2005) Domesticating forests: how farmers manage forest resources. CIFOR and ICRAF, Bogor, Indonesia. Available via Center for International Forestry Research. http://www. cifor.cgiar.org/publications/pdf_files/Books/BMichon0501E0.pdf. Accessed 15 Feb 2008

Michon G, de Foresta H (1997) Agroforests: pre-domestication of forest trees or true domestication of forest ecosystems? Neth J Agric Sci 45:451-462

Michon G, de Foresta H, Levang P, Verdeaux F (2007) Domestic forests: a new paradigm for integrating local communities' forestry into tropical forest science. Ecol Soc 12(2):24

Millennium Ecosystem Assessment (2005) Ecosystems and human well-being: synthesis. Island Press, Washington, DC. Available via Millennium Ecosystem Assessment. http://www.millennium assessment.org/en/index.aspx. Accessed 25 Jan 2008

Ranjit Daniels RJ (2001) Biodiversity of the Western Ghats-an overview. In: Gupta AK, Kumar A, Ramakantha V (eds) (2001) Research priorities in tropical rain forests in India-workshop held at Coimbatore in February 2001. Available via Wildlife Institute of India. http://www.wii.gov.in/ envis/rain_forest/chapter2.htm. Accessed 25 June 2009

Sarin M, Singh NM, Sundar N, Bhogal RK (2003) Devolution as a threat to democratic decision-making in forestry? Findings from three states in India. ODI Working Paper No 197. Overseas Development Institute (ODI), London. Available via ODI. www.odi.org.uk/resources/download/1765.pdf. Accessed 10 Feb 2008

Sourdril A, de du Bus Warnaffe G, Deconchat M, Balent G, de Garine E (2006) From farm forestry to farm and forestry in south-western France as a result of changes in a 'house-centred' social structure. Small-Scale For 5(1):127-144 
Sundar N, Jeffery R, Thin N (2001) Branching out: joint forest management in four Indian states. Oxford University Press, New York

Temperton VM (2007) The recent double paradigm shift in restoration ecology. Restor Ecol 15(2):344347

Wiersum KF (2004) Forest gardens as an 'intermediate' land-use system in the nature-culture continuum: characteristics and future potential. Agrofor Syst 61-62(1-3):123-134 